\title{
Needlestick and Sharps Injuries Among Operating Room Nurses, Reasons and Precautions
}

\section{Ameliyathane Hemşirelerinin Kesici-Delici Aletler ile Yaralanma Durumu, Nedenleri ve Önlemleri}

\author{
(i) Mahmut DAĞCI, iD Yazile YAZICI SAYIN
}

Bezmialem Vakıf University Faculty of Health Science, Department of Nursing, İstanbul, Turkey

\begin{abstract}
Objective: This study was carried out to determine the needlestick injuries (NSI) of the operating room nurses with penetrating and sharp tools, the causes of the injury and the precautions taken to prevent the injury.

Methods: A descriptive and cross-sectional study was conducted with the participation of 463 volunteer nurses from 27 different hospitals in Istanbul, Turkey. After obtaining the ethics committee, institutions and volunteer permissions of the study, the data were collected with two data collection forms formed in line with the literature knowledge and expert opinions. The data were analyzed using IBM SPSS 22.0 program and $\mathrm{p}<0.05$ was significance value.

Results: Participants were 18-61 years old, (mean: 35.9 \pm 0.84 ), $63.7 \%$ had bachelor's degrees and above, $80.8 \%$ of operating room nurses were graduated from nursing program. $68.9 \%$ of the participants reported that they had lived at least once during their working life. There were significantly different for NSI $(\mathrm{p}<0.05)$ women, married and had low educational levels, working in university hospitals with deep invasive intervention and using protective equipment. Participants reported that $54.8 \%$ of the injuries were performed in the right hand and the primary cause was exchanging instruments between nurse and surgeon, the secondary was assisting surgeon. Most of the participants (37.1\%) were injured by the suture material. The most common NSI encountered operating theaters were pediatric surgery, cardiovascular surgery, thoracic surgery and general surgery.
\end{abstract}

\section{ÖZ}

Amaç: $\mathrm{Bu}$ araştırma, ameliyathane hemşirelerinin delici kesici aletlerle yaralanma (DKAY) durumunu, yaralanma nedenlerini ve yaralanmadan korunmak için aldıkları önlemleri belirlemek amaciyla yapıldı.

Yöntemler: Tanımlayıcı ve kesitsel nitelikteki araştırma, Türkiye’nin İstanbul ilinin 27 farklı hastanesindeki 463 gönüllü hemşirenin katılımı ile yapıldı. Araştırmanın verileri, etik kurul, kurum ve gönüllü izinleri alındıktan sonra literatür bilgisi ve uzman görüşleri doğrultusunda oluşturulan farklı iki veri toplama formu ile toplandı. Veri analizinde IBM SPSS 22.0 programı kullanılarak anlamlılık $\mathrm{p}<0,05$ düzeyinde değerlendirildi.

Bulgular: Katılımcıların, 18-61 yaş (ortalama: 35,9 90,840 ) arasında, \%63,7'sinin lisans ve lisansüstü eğitim düzeyinde olduğu, $\% 80,8^{\prime}$ inin hemşire unvanı ile ameliyathane hemşiresi olduğu belirlendi. Katılımcıların \%68,9'u çalışma hayatları boyunca en az bir kez DKAY yaşadığını bildirdi. DKAY; kadın, evli ve eğitim düzeyi düşük, devlete bağlı üniversite hastanelerinde çalışan, koruyucu ekipman olanağı yeterli sağlanmayan/kullanmayan katılımcılarda daha fazlaydı, fark istatistiksel olarak anlamlıydı $(\mathrm{p}<0,05)$. Katılımcılar DKAY'nin nedeninin çoğunlukla cerrahi alet alısverişi/yardım edici davranışlar sırasında yaşanabildiğini bildirdi. DKAY yaşayan katılımcıların sağ elden yaralandıkları $(\% 54,8)$, en fazla yaralanmanın \%37,1 ile sutür materyalinden kaynaklandığı bulundu. Yaralanmanın en fazla yaşandığı ameliyathaneler sırasıyla çocuk cerrahisi, kardiyovasküler cerrahi, göğüs cerrahisi ve genel cerrahiydi.

Address for Correspondence: Mahmut DAĞCl, Bezmialem Vakıf University Faculty of Health Science, Department of Nursing, İstanbul, Turkey

E-mail: mdagci@bezmialem.edu.tr ORCID ID: orcid.org/0000-0003-0883-9129

Received: 25.04 .2020

Accepted: 21.05 .2020

Cite this article as: Dağcı M, Yazıcı Sayın Y. Needlestick and Sharps Injuries Among Operating Room Nurses, Reasons and Precautions. Bezmialem Science 2021;9(3):317-25. 
Conclusion: The results of the research show that NSI is an important problem related to healthcare workers' safety in operating theaters.

Keywords: Operating room, operating room nurses, needlestick injuries, risk factors, prevention
Sonuç: Araştırma sonuçları, DKAY’nin ameliyathane sağlık çalışanlarının güvenliğini etkileyecek kadar önemli bir sorun olduğunu göstermektedir.

Anahtar Sözcükler: Ameliyathane, ameliyathane hemşireleri, delici kesici alet yaralanmaları, risk faktörleri, önlem

\section{Introduction}

Needlestick injury (NSI) is among the leading occupational accidents and risks that healthcare workers are exposed to (1). Such injuries are seen as an important problem that most of the health workers face at least once during their professional life (2). NSI is considered as a risk factor especially for the surgical team in terms of employee health (3). Operating rooms within the hospital are the most risky places for NSI. Studies have shown that the health workers most exposed to NSI are nurses and physicians (4-6). It has been reported that NSI can be experienced for many reasons, especially the intensity of the intraoperative process, stress and factors related to the employees (7).

The Centers for Disease Control and Prevention pointed out that contact with blood and body fluids and its effects were mostly seen in nurses $(1,8)$. In the 2018 report of the EPINet ${ }^{\mathrm{TM}}$ database prepared for the surveillance of NSI and blood-borne infections, it was reported that NSI occured mostly in operating rooms and in nurses among all healthcare workers $(4,9)$. According to the data of the European Agency for Safety and Health at Work, approximately 1 million injuries occur in healthcare workers each year in Europe caused by injectors alone (10). Research emphasizes that the measures to be taken and the adoption of safety practices can reduce the NSI by $80 \%(11,12)$.

Although it is known that protective measures are necessary in the researches, it is reported that infectious diseases continue to be transmitted under the name of "work accident". When the studies conducted in this area are examined, it is seen that there are suggestions that it should be questioned whether the rate of NSI of nurses decreases in the face of developing science and technology (13-17).

The present study was carried out to determine the conditions of operating room nurses that caused NSI, the precautions they took to prevent injury, and to draw attention to the importance of this issue in the light of the literature.

Within the scope of the research purpose, answers were sought to the following questions;

1. What is the prevalence of NSI among operating room nurses?

2. Is NSI related to the sociodemographic characteristics of operating room nurses?

3. Is NSI related to the working conditions of operating room nurses?
4. What are the precautions taken regarding NSI in the conditions where the operating room nurses work?

\section{Methods}

\section{The Universe and Sample of the Research}

The "general universe" of the study, which was planned as a descriptive and cross-sectional study, was represented by the operating room nurses of 220 hospitals in İstanbul, including university, state, educational research and private hospitals (18). Among these hospitals, the "study universe" of the research was chosen. In the literature, attention is drawn to the risk of NSI in healthcare workers in training and research hospitals (19). Therefore, the "study universe" was composed of operating room nurses of training and research hospitals, state hospitals and university hospitals $(n=1266)$. Since the presented research was a master's thesis, it had to be completed within a certain time, so the research was limited to the Istanbul European region. Thus, the study population consisted of 570 operating room nurses working in 27 hospitals. Since it was aimed to reach the whole research universe, no sample calculation was made. While collecting the data, nurses who were in surgery $(n=25 ; 4.38 \%)$, who did not want to participate in the study $(n=47 ; 8.24 \%)$ or who were sick $(n=35 ; 6.13 \%)$ were excluded from the study. The research was completed with a participation rate of $81.2 \%$. Thus, a total of 463 nurses participated in the study.

\section{Data Collection Tools}

Data were collected with a questionnaire developed in line with the literature (20-23) and expert opinions. Survey form included 42 closed questions that determined the socio-demographic characteristics of the operating room nurses, their situations and reasons for NSI, and their and their institutions' approaches to the measures taken to prevent NSI. In order to evaluate the clarity of the questions, a preliminary study was carried out with approximately $10 \%$ of the sample number $(n=47)$. After the preliminary study, the questions in the data collection form were rearranged and it was decided to use the revised form.

\section{Data Collection}

Methods based on "self-report" were used in data collection.

After the necessary permissions were completed, the operating rooms of the hospitals where the research would be conducted were visited according to a pre-planned schedule (between 23.01.2017 and 28.08.2017). Information about the research was given by interviewing with the operating room nurse in charge of each hospital about the questionnaire forms, the 
importance of the study to be conducted and ethical permissions. Questionnaires and voluntary consent forms were delivered to the nurses. A second visit was made by c ontacting the nurse in charge within 10-15 days to collect the forms distributed by the researcher.

\section{Evaluation of Data}

Data were analyzed in IBM SPSS 22.0 package program. Statistical significance of the data was analyzed with Pearson Chi-Square Test, Pearson Correlation Test, Fisher's Exact test, t-Test, and f-test (ANOVA) according to the distribution status of the data. Significance was evaluated at the $95 \%$ confidence level and at the $\mathrm{p}<0.05$ level.

\section{Ethical Considerations}

The study was approved by the Bezmialem Vakıf University Noninterventional Clinical Research Ethics Committee (29.11.2016 8/93). Institutional permissions were taken from the rectors of university hospitals, and from the general secretariats of the public hospitals to which they were affiliated. Voluntary participation consent was obtained from the participants in writing.

\section{Results}

In this section, there are introductory and comparative findings obtained with the aim of assessing the participants' NSI status.

In the present study, it was determined that $80.8 \%$ of the participants were female, $19.2 \%$ were male, $57 \%$ were married, $42.8 \%$ were between 29-39 years old (mean age 35 \pm 0.840 ), and $63.7 \%$ had undergraduate or higher education level. It was determined that $80.8 \%$ of the operating room nurses graduated from a nursing program, $41.7 \%$ worked in training and research hospitals, and $53.6 \%$ had 7 years or more of operating room nursing experience. In addition, it was determined that $68.9 \%$ of the participants reported that they had experienced NSI (Table 1).

Table 2 shows some of the characteristics of the participants about NSI. Of the participants $28.3 \%$ stated that they experienced NSI during the exchange of surgical instruments, $16.3 \%$ during assisting the surgeons, and $15.3 \%$ during collecting and counting of surgical instruments. It was reported that injuries were most common in the hand $(96.8 \%)$, with $54.8 \%$ of the injuries occurring in the right hand. In $37.7 \%$ of the nurses suture material and in $28.2 \%$ scalpel were shown as the instrument causing injury.

When the socio-demographic characteristics of the participants were compared with NSI, it was found that female participants were more likely to encounter NSI than male participants $(\mathrm{p}=0.007)$, and that married participants were more likely to encounter NSI than singles $(\mathrm{p}=0.002)$. Although the frequency of NSI increased with increasing age, there was no statistically significant difference $(\mathrm{p}=0.607)$. As the level of education increased, frequency of NSI also increased and the difference was statistically significant $(\mathrm{p}=0.016)$ (Table 3$)$.
Table 4 shows the comparison of the characteristics of the participants with NSI. In the operating room nurses of state university hospitals, NSI was less than the others, but the difference was not statistically significant $(\mathrm{p}=0.938)$. Although the nurses working in the pediatric surgery $(81.3 \%)$, thoracic surgery and cardiovascular surgery $(78.2 \%)$, and general surgery (77.1\%) operating rooms reported more NSI compared to the other operating rooms, the difference was not statistically significant $(\mathrm{p}=0.651)$.

It was observed that as the working years as an operating room nurse, the duration of working hours in a shift, and the average time spent in surgery increased, the frequency of NSI increased $(\mathrm{p}=0.01)$, and working in a mixed shift system was significantly related with NSI $(\mathrm{p}=0.001)$.

NSI was less in healthcare workers $(n=58)$ employed as operating room nurses than in nurses. However, this difference was not statistically significant $(\mathrm{p}=0.235)$.

Table 5 shows the comparison of the participants' NSI status according to the security measures taken. Difficulty in finding protective equipment showed an insignificant relationship with the NSI status $(\mathrm{p}=0.887)$. However, as the use of protective equipment increased, it was observed that the NSI decreased and the difference was statistically significant $(\mathrm{p}=0.001)$. When the precautions the participants took against NSI were examined, it was determined that the practices such as the use of double gloves and control of patient serology did not make a difference for participanst with and without NSI $(\mathrm{p}<0.05)$.

\section{Discussion}

In the present study, the fact that the majority of the participants are young, married, had a high level of education and were working in the operating room for a long time suggested that this group consisted of dynamic and high-conscious individuals with a regular family life. It could be concluded that the presented study was similar to the studies published in the national and international literature in terms of socio-demographic characteristics (2,24-29). In addition, the fact that the majority of the participants were state hospital employees might be related to the fact that the participants preferred institutions with more personal rights, or it might be due to the selection of samples.

According to OECD (Organization for Economic Co-operation and Development) 2018 data, the number of nurses providing care to every 1000 citizens was 17.8 in Norway, 17.2 in Switzerland, 14.8 in Iceland, while it was 2.1 in Turkey, which was far behind the OECD average (30). In the presented study, the fact that most of the nurses worked in random units and mixedshift system in the operating room suggested that nurses worked under hard conditions according to OECD recommendations and their conditions regarding employee safety were risky. In the study conducted by Kan (31), it was reported that $29.4 \%$ of the operating room nurses were distracted at the $4^{\text {th }}$ hour, that the distraction peaked at the $6^{\text {th }}$ hour, and that there was a relationship between prolonged surgeries and NSI in $94.1 \%$ of the operating 
Table 1. Descriptive characteristics of the participants ( $n=463$ )

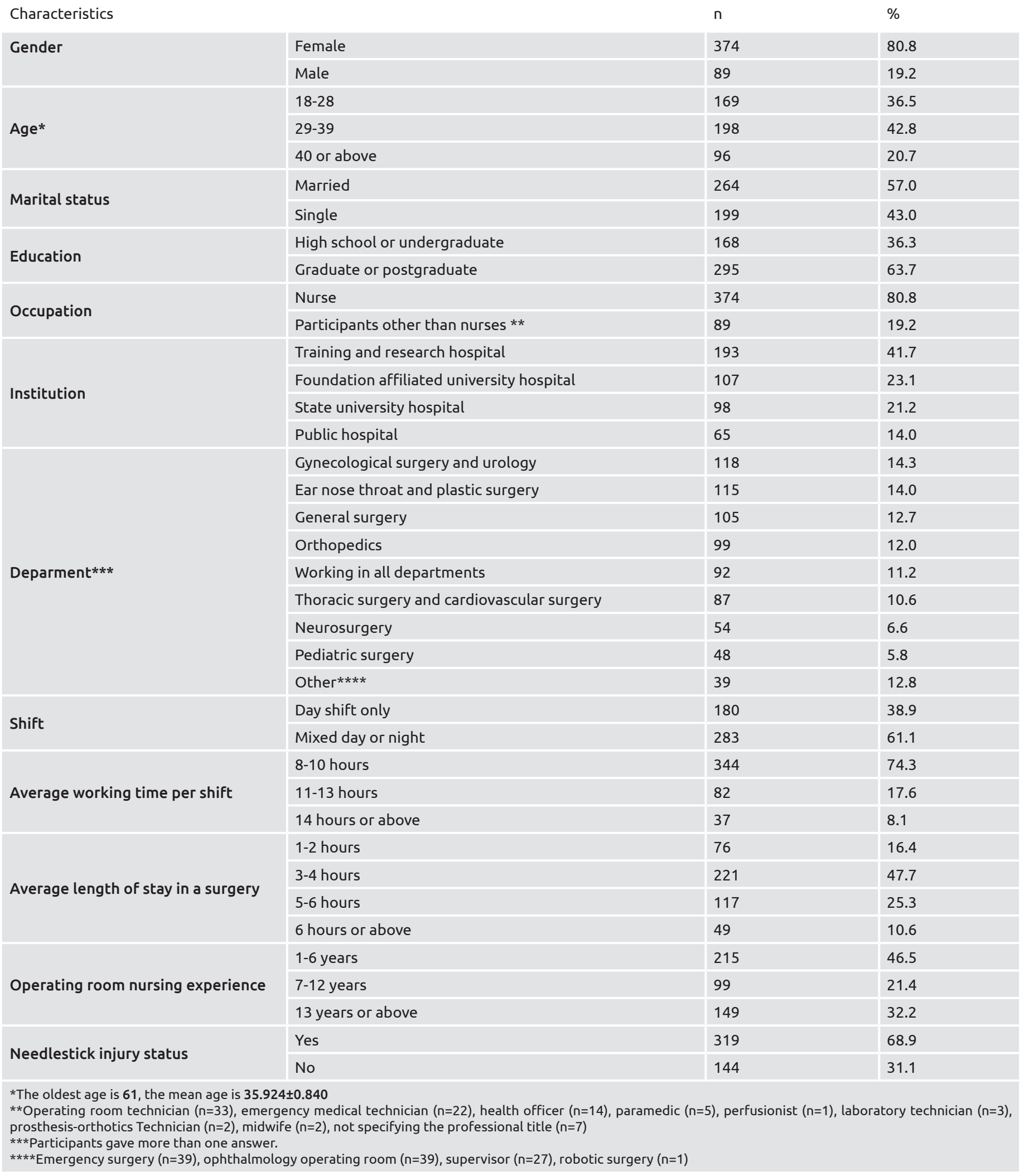

room nurses (31). The NSI rates of nurses in the present study (Table 1) were similar to some developing countries, suggesting that operating room nurses expected solutions for similar risks internationally (32). Zhang et al. (33) reported the rate of NSI as $84.6 \%$ in China, Kasatpibal et al. (2) $71.5 \%$ in Thailand, Yazar et al. (34) 65.8\%, and Benli et al. (35) $77.9 \%$ (33). It is 
Table 2. Some characteristics of the participants about needlestick injury

Needlestick injury characteristics

Causes of injury*

Injured organ*

\begin{tabular}{|c|c|c|}
\hline & n & $\%$ \\
\hline While exchanging drilling-cutting tool & 279 & 28.3 \\
\hline While assisting the surgeon & 161 & 16.3 \\
\hline During the collection and counting of instruments & 151 & 15.3 \\
\hline When using an injector & 117 & 11.9 \\
\hline In emergency surgeries/events & 105 & 10.7 \\
\hline While preparing the surgery table & 56 & 5.7 \\
\hline During the use of the Sharp-Box & 49 & 5.0 \\
\hline While controlling medical wastes in surgical instrument loss & 27 & 2.7 \\
\hline During washing and packaging of surgical instruments & 22 & 2.2 \\
\hline Other (responsible nurse, robotic surgery...) & 18 & 1.8 \\
\hline Right hand & 256 & 54.8 \\
\hline Left hand & 196 & 42.0 \\
\hline Other (arms, head, neck, trunk, eye ...) & 15 & 3.2 \\
\hline Suture material & 245 & 37.7 \\
\hline Lancet & 183 & 28.2 \\
\hline Injector/IV catheter & 144 & 22.2 \\
\hline Other** & 78 & 12.0 \\
\hline Always having trouble & 62 & 13.4 \\
\hline Sometimes can't find & 180 & 38.9 \\
\hline Available whenever & 221 & 47.7 \\
\hline Always & 209 & 45.1 \\
\hline Sometimes & 88 & 19.0 \\
\hline Never & 13 & 2.8 \\
\hline Only in infected cases & 153 & 33.0 \\
\hline In all surgeries & 166 & 35.9 \\
\hline Not used & 188 & 40.0 \\
\hline Used during preoperative skin asepsis & 45 & 9.7 \\
\hline Other*** & 64 & 13.8 \\
\hline Always & 284 & 61.3 \\
\hline Sometimes & 143 & 30.9 \\
\hline Never & 36 & 7.8 \\
\hline
\end{tabular}

Injuring instrument*

Provision of protective equipment

The use of protective equipment in surgeries

Use of double gloves during surgery

\section{Checking patient serology before surgery}

* Participants gave more than one answer.

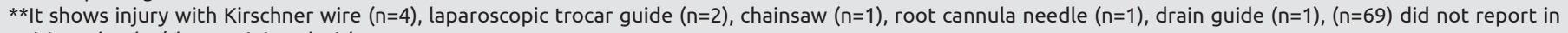
writing what he/she was injured with.

$* * *$ Infected cases $(n=44)$, Orthopedic surgery $(n=20)$

controversial that gender is a risk factor for NSI (32-36). Afridi et al. (36) in Pakistan compared the gender of participants (35.8\% male and $64.2 \%$ female) in terms of NSI and reported that gender did not show a significant difference in terms of NSI. In the present study, the reason for the significantly higher NSI in females was the lower number of male participants. With the increase in age, it is expected that the NSI will decrease as the experience, education level and knowledge increase. Educational level may not be a determining risk factor for NSI, as it does not always indicate skill level in clinical practice. However, education can provide awareness of the problem and accelerate finding solution by organizing against the problem (37). In the study presented, it is believed that trained and experienced nurses were more likely to face DKAY because they participated in operations more due to their age and faced risk (Table 3 ).

In the present study, when the causes of NSI were examined, it was thought that the "hands-free" technique was not used effectively, especially in the operating rooms, as the participants reported that they were injured by instruments with stinging and cutting 
Table 3. Comparison of participants' socio-demographic characteristics with needlestick injury status ( $\mathrm{n=463)}$ Needlestick injury status

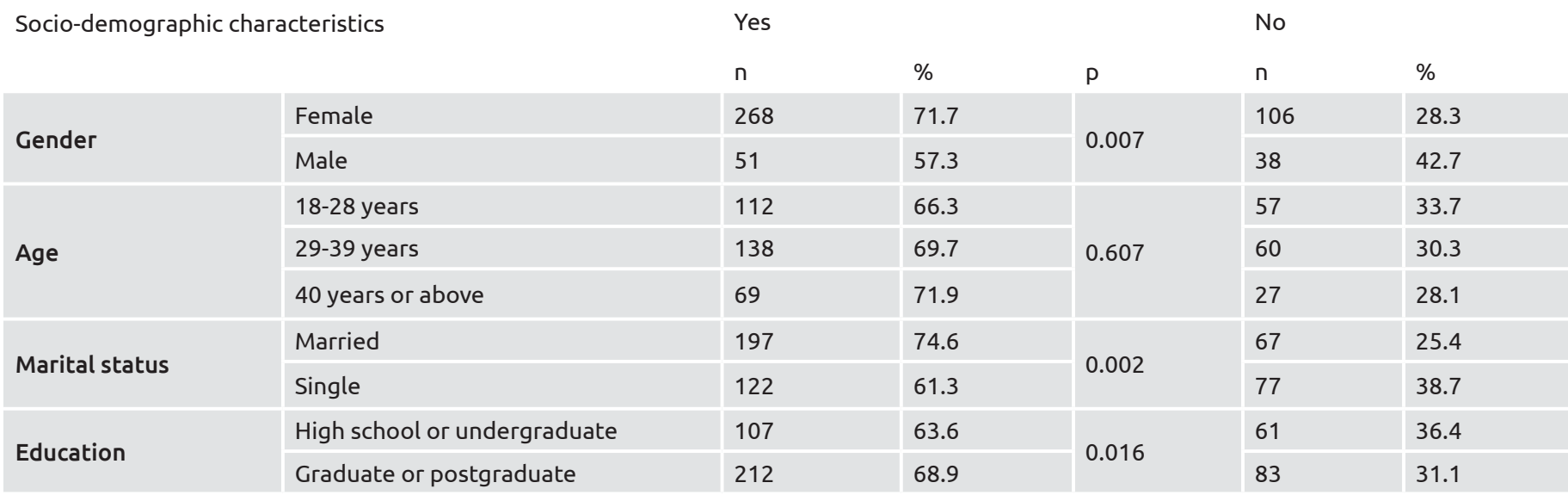

Table 4. Comparison of the participants' working life characteristics with needlestick injury status ( $n=463)$

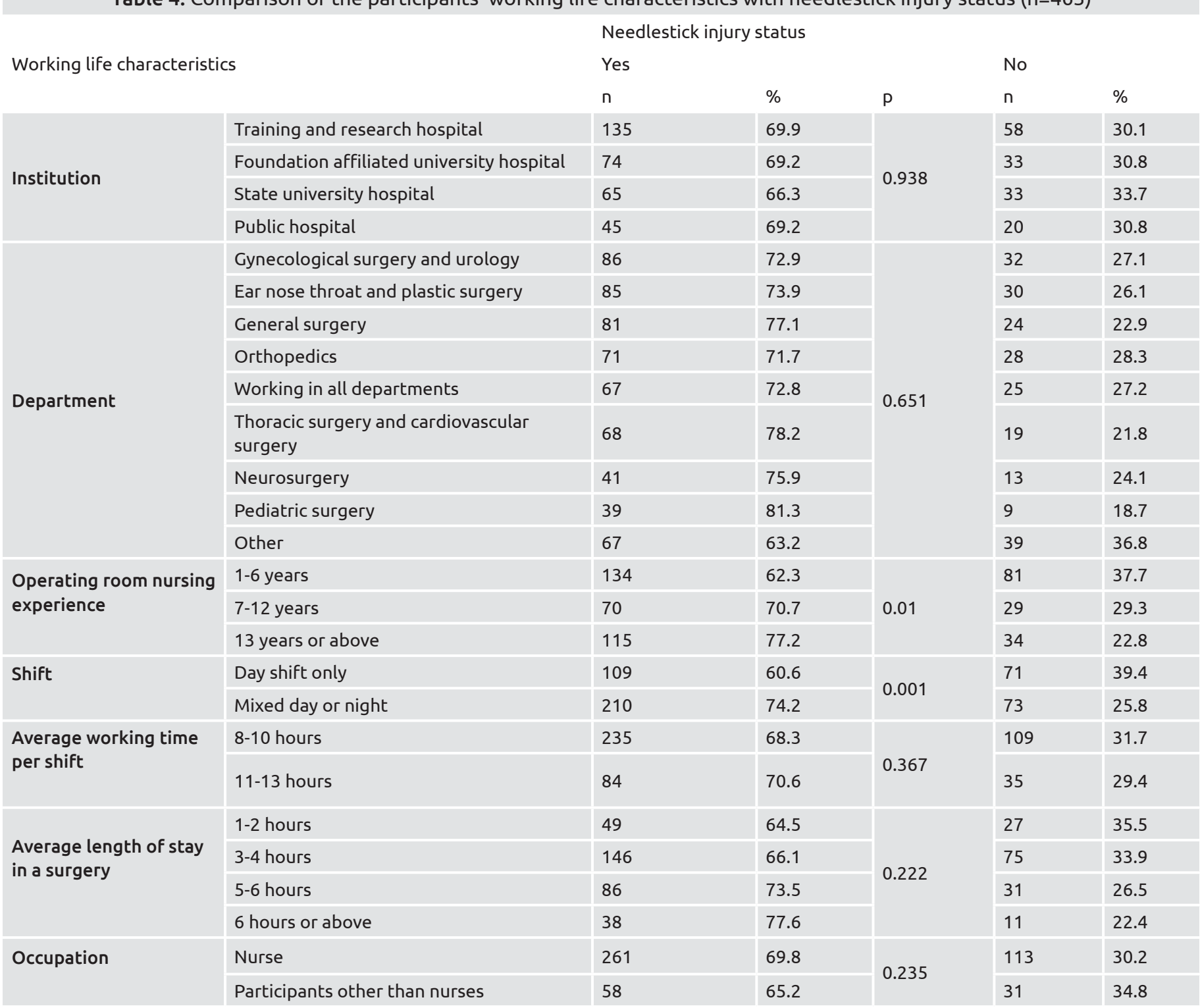


Table 5. Comparison of the participants' needlestick injury status according to the security measures taken ( $\mathrm{n}=463$ )

Security measures

Needlestick injury status

\begin{tabular}{|c|c|c|c|c|c|c|}
\hline & & Yes & & & No & \\
\hline & & $n$ & $\%$ & $p$ & n & $\%$ \\
\hline & Always having trouble & 44 & 71.0 & & 18 & 29.0 \\
\hline Provision of protective equipment & Sometimes can't find & 122 & 67.8 & 0.887 & 58 & 32.2 \\
\hline & Available whenever & 153 & 69.2 & & 68 & 30.8 \\
\hline & Always & 126 & 60.3 & & 83 & 39.7 \\
\hline The use of protective equipment in & Sometimes & 59 & 67.0 & & 29 & 33.0 \\
\hline surgeries & Never & 9 & 69.2 & 0.001 & 4 & 30.8 \\
\hline & Only in infected cases & 125 & 81.7 & & 28 & 18.3 \\
\hline & In all surgeries & 111 & 66.9 & & 55 & 33.1 \\
\hline & Not used & 137 & 72.9 & & 51 & 27.1 \\
\hline Use of double gloves during surgery & $\begin{array}{l}\text { Used during preoperative skin asepsis } \\
\text { before surgery }\end{array}$ & 32 & 71.1 & 0.296 & 13 & 28.9 \\
\hline & $\begin{array}{l}\text { In orthopedic surgeries and infected } \\
\text { cases }\end{array}$ & 39 & 60.9 & & 25 & 39.1 \\
\hline & Always & 193 & 68.0 & & 91 & 32.0 \\
\hline Checking patient serology before surgery & Sometimes & 102 & 71.3 & 0.743 & 41 & 28.7 \\
\hline & Never & 24 & 66.7 & & 12 & 33.3 \\
\hline
\end{tabular}

properties while exchanging surgical instruments and helping the surgeon. Penetrating tools used in the operating room are generally capable of causing injuries such as cutting, puncturing, and scratching $(37,38)$. However, Stringer et al. (39) reported that the injury rate was $1.2 \%$ in surgeries using the "hands-free technique" and $4.0 \%$ in surgeries that did not use. In another study, Stringer et al. (40) reported that the "hands-free technique" and the visual materials used in the training of this technique were effective in reducing the NSI. Jagger and Perry (41) reported that the use of the same technique was effective in their study. Considering the studies on the properties of the injurious agent; Kürtünlü (42) showed that suture material (41.5\%) and scalpel (38.4\%), Mohammad (43) injector needles (45\%) and surgical sutures (30\%), Lakbala et al. (27) sutures (59\%), Hajipour (44) sutures (43.4\%), and Wada et al. (26) sutures (48.3\%) were the most common causes of injury. The fact that the majority of the injured participants in the present study experienced injury during pediatric and cardiac surgery operations might be related to the physical properties of the instruments used in these operations and the surgical technique. In these surgeries, small suture materials that force hand manipulation are used or deep invasive procedures are performed.

It has been suggested that while double-layered and different colored indicator gloves used in surgery reduce the risk of NSI, wearing single-colored standard gloves on each other creates an unnecessary sense of security (45). Makama et al. (46) reported that $15.2 \%$ of the gloves worn in single layer, $27.5 \%$ of the outer part of the gloves worn in double layer and $1.2 \%$ of the inner part of the gloves worn in double layer were not damaged.
Demircay et al. (47) reported that the outer part of $18.4 \%$ and the inner part of $8.4 \%$ of the double-layered gloves were not damaged. Guo et al. (48) reported that $11.3 \%$ of the outer part of gloves that were worn double layer were torn while the inner part was intact, and that $8.9 \%$ of the gloves that were worn in one layer were torn (46-48). In the presented study, it was seen that double layer gloves were used in a rate which could not be underestimated. This situation might lead healthcare workers to more risky interventions by feeling more secure and might increase the rates of NSI.

According to the findings of the study presented, the nurses were unable to realize standard protection measures related to NSI and they reported that they had difficulties in finding equipment to protect against NSI. This might be due to the characteristics of the hospitals where the participants worked, because while private hospitals had to live on their own capital, state hospitals might have difficulty in supplying materials due to excessive patient load. In a study conducted by Özenir (49) in a private hospital in Turkey, it was reported that $79 \%$ of nurses had difficulty in accessing protective equipment.

\section{Study Limitations}

During the study, it was learned that different occupational groups (emergency medical technician, paramedic, midwife, perfusionist, prosthesis-orthotics technician, operating room technician) were employed under the name of operating room nurse in some institutions where the study was conducted (19.2\%). Since these non-nurses were employed as operating room nurses, it was thought that it would be unethical to exclude 
them from the sample, as they were considered to be at risk in terms of NSI. Discussing the results of these healthcare workers, who did not have nursing education, regarding NSI may have limited the observation of the nurses' injury status.

Unfortunately, many healthcare graduates are employed as nurses in hospitals for various reasons, although they do not graduate from nursing schools. In this case, examining and presenting these health workers' NSI separately may have correct results in many respects.

\section{Conclusion}

According to the findings of the study, the operating room nurses encounter a significant number of NSI. The conditions related to the institution where they work/employ rather than their sociodemographic characteristics play a prominent role in NSI. The fact that the majority of NSI is preventable indicates that institutional policies should change. It is recommended to investigate the causes and consequences of institutional sanctions in order to achieve the expected goals with experienced, highly educated nurses employed in the operating room.

\section{Ethics}

Ethics Committee Approval: The study was approved by the Bezmialem Vakıf University Non-interventional Clinical Research Ethics Committee (29.11.2016 8/93).

Informed Consent: Voluntary participation consent was obtained from the participants in writing.

Peer-review: Externally peer reviewed.

\section{Authorship Contributions}

Concept: M.D., Y.Y.S., Design: M.D., Y.Y.S., Data Collection or Processing: M.D., Analysis or Interpretation: M.D., Y.Y.S., Literature Search: M.D., Y.Y.S., Writing: M.D., Y.Y.S.,

Conflict of Interest: No conflict of interest was declared by the authors.

Financial Disclosure: The authors declared that this study received no financial support.

\section{References}

1. Centers for Disease Control and Prevention. Workbook for designing, implementing, and evaluating a sharps injury prevention program. 2008. Available from: URL: https:/www.cdc. gov/sharpssafety/pdf/sharpsworkbook_2008.pdf.

2. Kasatpibal N, Whitney JD, Katechanok S, Ngamsakulrat S, Malairungsakul B, Sirikulsathean P, et al. Prevalence and risk factors of needlestick injuries, sharps injuries, and blood and body fluid exposures among operating room nurses in Thailand. Am J Infect Control 2016;44:85-90.

3. Adams S, Stojkovic SG, Leveson SH. Needlestick injuries during surgical procedures: a multidisciplinary online study. Occup Med (Lond) 2010;60:139-44.
4. Leigh JP, Wiatrowski WJ, Gillen M, Steenland NK. Characteristics of persons and jobs with needlestick injuries in a national data set. Am J Infect Control 2008;36:414-20.

5. Motaarefi H, Mahmoudi H, Mohammadi E, Hasanpour-Dehkordi A. Factors Associated with Needlestick Injuries in Health Care Occupations: A Systematic Review. J Clin Diagn Res 2016;10:1-4.

6. Akyol AD, Kargın C. Needle Stick and sharp injuries among nurses. Glob J Nurs Forensic Stud 2016;1:1000109.

7. Verbeek J, Basnet P. Incidence of sharps injuries in surgical units, a meta-analysis and meta-regression. Am J Infect Control 2019;47:44855.

8. Mullan RJ, Baker EL, Hughes JM, Bell DM, Jaffe HW, Bond WW, et al. Guidelines for prevention of transmission of human immundeficiency virus and hepatitis-B virus to health-care and public-safety workers. Morbidity and Mortality Weakly Report 1989;38:1-37.

9. European Agency for Safety and Health at Work (OSHA-EU): How to reduce workplace accidents. 2001 Available from: URL:https:// osha.europa.eu/en/publications/report-how-reduce-workplaceaccidents

10. International Healthcare Worker Safety Center, University of Virginia. U.S.EPINet Sharps Injury and Blood and Body Fluid Exposure Surveillance Research Group. Needlestick and sharps object injuries report for 2018. Avaliable from: URL:https:// internationalsafetycenter.org/wp-content/uploads/2019/07/Official2018-US-NeedleSummary-FINAL.pdf.

11. Visser L. Toronto hospital reduces sharps injuries by $80 \%$, eliminates blood collection injuries. A case study: Toronto East General Hospital pioneers healthcare worker safety. Healthc Q 2006;9:68-70.

12. Jeong IS, Park S. Use of hands-free technique among operating room nurses in the Republic of Korea. Am J Infect Control 2009;37:131-5.

13. Beşer A. Health risks and management of health care workers. Dokuz Eylül University Nursing Journal 2012;5:39-44.

14. Turan H, Togan T. The Evaluation of Injuries Related to Blood and Body Fluids among Healthcare Workers. Klimik Journal 2013;26:98101.

15. Dekker S. Patient safety: a human factors approach. 1st edition. New York: CRC Press; 2011.

16. Yassi A, Hancock T. Patient safety--worker safety: building a culture of safety to improve healthcare worker and patient well-being. Healthc Q 2005;8:32-8.

17. Clarke SP, Schubert M, Körner T. Sharp-device injuries to hospital staff nurses in 4 countries. Infect Control Hosp Epidemiol 2007;28:473-8.

18. Istanbul Provincial Health Directorate. List of hospitals in Istanbul. Access From: URL: http://istanbulism.saglik.gov.tr/TR,50448/ saglik-kurumlari.html

19. Öztürk R. HIV infection: Prevention, control and vaccination. Turkiye Klinikleri Journal of Internal Medical Sciences 2007; 3: 93-9.

20. Okutan S, Saritas S. Determining applications and knowledge about the injuries caused by surgical tools in nurses working in surgical units (dissertation).. Malatya: İnönü Univ. 2016. 
21. Yıldız K. The evolution of the safe usage of sharp devices by the health care workers (dissertation). İzmir: Ege Univ. 2011.

22. Ceylan C. The examination of injuries which are based on the declarations of nurses working in a university hospital (dissertation). İzmir: Dokuz Eylül Univ. 2009.

23. Kutlu D. The research of risk of surgical staff's injuries with surgical insruments in the operating room and factors which influence it (dissertation). Afyon: Afyon Kocatepe Univ. 2007.

24. Fathi Y, Barati M, Zandiyeh M, Bashirian S. Prediction of Preventive Behaviors of the Needlestick Injuries during Surgery among Operating Room Personnel: Application of the Health Belief Model. Int J Occup Environ Med 2017;8:232-40.

25. Rishi E, Shantha B, Dhami A, Rishi P, Rajapriya HC. Needle stick injuries in a tertiary eye-care hospital: Incidence, management, outcomes, and recommendations. Indian J Ophthalmol 2017;65:9991003.

26. Wada K, Yoshikawa T, Lee JJ, Mitsuda T, Kidouchi K, Kurosu H, et al. Sharp injuries in Japanese operating theaters of HIV/AIDS referral hospitals 2009-2011. Ind Health 2016;54:224-9.

27. Lakbala P, Sobhani G, Lakbala M, Inaloo KD, Mahmoodi H. Sharps injuries in the operating room. Environ Health Prev Med 2014;19:348-53.

28. Seyman Ç, Ayaz S. Opinions of operating room nurses regarding patient and staff safety in operating room. Dicle Medical Journal 2016;43:12-7.

29. Özyiğit F, Küçük A, Arıkan İ, Altuntaş Ö, Kumbasar H, Fener S, et al. The attitude of healthcare workers to safe use of medical instruments in a training and research hospital. The Medical Bulletin of Haseki 2014; 10: 168-71.

30. OECD. Nurses (indicator) 2020. doi:10.1787/283e64de-en Avaliable from: URL:https://data.oecd.org/healthres/nurses.htm

31. Kan N. Nurses working in the operating room drills-cutting tools, and factors affecting the risk of injury (dissertation). İstanbul: İstanbul Bilim Univ. 2013.

32. Chiannilkulchai N, Kejkornkaew S. A Comparative study of ampoule breaking and resultant injury among registered nurses. Pacific Rim International Journal of Nursing Research 2020;24:89-101.

33. Zhang X, Gu Y, Cui M, Stallones L, Xiang H. Needlestick and Sharps Injuries Among Nurses at a Teaching Hospital in China. Workplace Health Saf 2015;63:219-25.

34. Yazar S, Yücetaş U, Özkan M, Zulcan S. Research regarding injuries to health workers by surgical and other potentially dangerous medical tools and precautions against such injuries. İstanbul Med J 2016;17:5-8.
35. Benli AR, Özenver F, Sürmen S, Kayış SA, Koyuncu M, Sunay D. Knowledge, attitude and behaviours of hospital staff with regard to the occupational health and safety. Turkish Journal of Family Medicine and Primary Care 2016;10:188-95.

36. Afridi AA, Kumar A, Sayani R. Needle stick injuries--risk and preventive factors: a study among health care workers in tertiary care hospitals in Pakistan. Glob J Health Sci 2013;5:85-92.

37. Omaç M, Eğri M, Karaoğlu L. Evaluation of occupational needlestick-sharp injuries and status of hepatitis B immunization on nurses working at Malatya province hospitals. Journal of Inönü University Medical Faculty 2010;17:19-25.

38. Moro PL, Moore A, Balcacer P, Montero A, Diaz D, Gómez V, et al. Epidemiology of needlesticks and other sharps injuries and injection safety practices in the Dominican Republic. Am J Infect Control 2007;35:552-9.

39. Stringer B, Infante-Rivard C, Hanley JA. Effectiveness of the handsfree technique in reducing operating theatre injuries. Occup Environ Med 2002;59:70.

40. Stringer B, Haines T, Goldsmith CH, Blythe J, Berguer R, Andersen J, De Gara CJ. Hands-free technique in the operating room: reduction in body fluid exposure and the value of a training video. Public Health Rep 2009;124:169-79.

41. Jagger J, Perry J. Power in numbers: using EPINet data to promote protective policies for healthcare workers. J Infus Nurs 2002;25:1520.

42. Kürtünlü Ş. Determination of the injuries of operations room staff by sharp or penetrating tools (dissertation). İstanbul: Haliç Univ. 2013.

43. Mohammad A. Needlestick and sharps injuries among resident physicians: an institutional review. Conn Med 2014;78:9-15.

44. Hajipour B. Scalpel safety and new scalpel blade remover. J Pak Med Assoc 2011; 61: 943-5.

45. Tanner J, Parkinson H. Double gloving to reduce surgical crossinfection. Cochrane Database Syst Rev 2006;2006:CD003087.

46. Makama JG, Okeme IM, Makama EJ, Ameh EA. Glove Perforation Rate in Surgery: A Randomized, Controlled Study To Evaluate the Efficacy of Double Gloving. Surg Infect (Larchmt) 2016;17:436-42.

47. Demircay E, Unay K, Bilgili MG, Alataca G. Glove perforation in hip and knee arthroplasty. J Orthop Sci 2010;15:790-4.

48. Guo YP, Wong PM, Li Y, Or PP. Is double-gloving really protective? A comparison between the glove perforation rate among perioperative nurses with single and double gloves during surgery. Am J Surg 2012;204:210-5.

49. Özenir S. Determining the attitudes towards the safe use of medical devices by occupational accidents that health workers are exposed to (dissertation). İstanbul: Acıbadem Univ. 2017. 